\title{
Left-Right Determination Factor 1
}

National Cancer Institute

\section{Source}

National Cancer Institute. Left-Right Determination Factor 1. NCI Thesaurus. Code C26348.

Left-right determination factor 1 (366 aa, $41 \mathrm{kDa}$ ) is encoded by the human LEFTY1 gene. This protein is involved in embryonic left/right axis determination. 